\title{
Pleonastic Application Of Synonyms In Alisher Navoi's Works
}

\author{
${ }^{1}$ Yusubova Rano Norboevna, ${ }^{2}$ Yarashova Nasiba Jumaevna \\ ${ }^{1}$ Ph.D., Associate Professor, Head of the Uzbek Language Department, Navoi State Pedagogical Institute, Uzbekistan. \\ ${ }^{2}$ Ph.D., Uzbek Language Department, Navoi State Pedagogical Institute, Uzbekistan.
}

\begin{abstract}
This article discusses the wide range of possibilities of the old Uzbek language in the example of Navoi's work led linguists to study the linguistic features of the poet's legacy on a deep scientific basis, which led to theoretical conclusions about the phoneticphonological, morpheme-morphological, lexical-semantic and syntactic levels of the old Uzbek literary language. For today's linguists, it is important to study the lexical structure of literary works before Navoi, to compare the lexicon of the ancient Turkic language, the Old Turkic language and the old Uzbek language, to study the history of the Uzbek language. Identifying semantic differences in the semantics of synonymous lexemes, the works of A. Navoi serve as one of the main sources in the study of the historical roots of the Uzbek language, as well as in the study of the lingvo-poetic potential of language units. The lingvo-poetic possibilities of assimilation synonyms used pleonastically in a verse or byte further clarify these views.
\end{abstract}

Keywords:

Ancient Turkic language, Uzbek language, A. Navoi, lingvo-poetic, the phonetic-phonological, morpheme-morphological, lexicalsemantic, syntactic levels, pleonastic application of synonyms, literary language.

Article Received: 18 October 2020, Revised: 3 November 2020, Accepted: 24 December 2020

\section{Introduction}

The language of a particular nation is formed, aligned and standardized on the basis of long-term historical processes. It clearly shows the features of the ancestors and nation's mentality, the national character, the priceless spirituality. The richness and power of the language of the nation manifests itself in fiction as a whole, for fiction is an extraordinary form of art that is verbally constructed, distinguished from others by its scale and expression. The role of the unique literary heritage created by our great ancestors in the survival, enrichment and survival of the Uzbek language for thousands of years is enormous. In this sense, for five centuries we have been proud of the permanence of the creative heritage of Alisher Navoi, who had a very strong and effective influence on the formation and development of the Uzbek language.

The wide range of possibilities of the old Uzbek language in the example of Navoi's work led linguists to study the linguistic features of the poet's legacy on a deep scientific basis, which led to theoretical conclusions about the phonetic- phonological, morpheme-morphological, lexicalsemantic and syntactic levels of the old Uzbek literary language. In the 15th century, Navoi managed to develop the old Uzbek language, raise its status to the level of the state language and the language of fiction, enriching the lexicon with synonymous assimilations, some Turkic grammatical forms, especially pure Turkish lexemes. In the language of Alisher Navoi's works, about 1,400 ancient Turkic lexical units related to various aspects of social life were in use. [1]. For today's linguists, it is necessary to study the lexical structure of literary works before Navoi, to compare the lexicon of the ancient Turkic language, the old Turkic language and the old Uzbek language, to study the history of the Uzbek language. Identifying semantic differences in the semantics of synonymous lexemes, the works of A. Navoi serve as one of the main sources in the study of the historical roots of the Uzbek language, as well as in the study of the lingvo-poetic potential of language units. The lingvo-poetic possibilities of assimilation 
synonyms used pleonastically in a verse or byte further clarify these views.

\section{Materials and Methods}

In the 15th century, Alisher Navoi was the first to conduct a comparative analysis of two unrelated languages, Turkic and Persian, by expressing objective views on the lexical richness of the old Uzbek language in his work called Muhokamat-ul Lughatayn. In this regard, Navoi provides comparison of the two languages, in many cases, the scholar proves the advantage of the Turkic language over Persian in terms of language expression capacity, highly avoiding discriminating against the Persian language by increasing the importance of his native language.

Alisher Navoi compares the Turkic language verbs, words belonging to the noun family, first of all, kinship terms, names of animals and birds, natural phenomena with Persian words and proves on the basis of examples that Uzbek vocabulary is superior to Persian.

Navoi's views on Turkic and Arabic synonyms and their use in Persian are noteworthy. In the modern Uzbek literary language there is the lexeme "yashin or chaqmoq" which has the meaning "atmospheric electric charge", Navoi writes about the lexeme of " chaqin" ( also means lightning), which is synonymous with the lexeme "Ildirim" archaic equivalent of lightning in this way:

Original "Сорт тилида чоқин ва илдиримдек мутааййин ва муътабар икки нимава от куймайдурурлар ва араб тили била барқ ва соиқа била адо қиилибдурлар" (Muhokamat-ul lug'atayn).

Meaning in English: "In the Sort ( the Old Turkic) language, they do not give the same names to two things that have slightly separate and certain meanings such as " chaqin and ildirim" (mean lighting), and in Arabic they do it with lightning and thunder." (Muhokamat-ul lug'atayn).

Synonyms occur according to the homogeneity of the unifying meaning, not a single concept, and the components in the semantic structure differ from each other in meaning semantics, because we know that synonymous series lexemes do not mean a single word, even though the unifying stemma in synonyms is one. While synonymy becomes the main source for the formation of poetic words, words belonging to the Arabic language perform only a poetic function here. It has been observed that poetic words stand out if some synonymous lines are addressed. These include:

Original examples:

a) айрилиқ, жудолик, хзижрон, хзажр, фироқ; б) ёруғ, нурли, ёрқин, мунаввар, порлоқ, равшан, нурафшон, анвор; в) кўкрак, ку̌кс, бағир, сийна, тўш, ўмров; г) аён, ошкор, зохир; д) мақсад, ният, муддао, мурод; е) одат, расм, таомил, удум, урф, анъана; ё) халк, халойик, раият, улус, мардум каби.

a) separation, loss, migration, pilgrimage, separation; b) light, radiant, bright, enlightened, brightly shining, shiny, full of light; c) chest, bust, breasts, abdomen; d) obvious, clear, apparent; e) purpose, intention, aim, goal; f) habit, usual, ritual, custom, tradition; g) people, crowd, citizen, nation, tribe.

Symbolism, figurative meaning, allegorical applications are considered as predominant and leading in Turkic classical literature in the expression of images, for example, a person who has a constant feeling of extreme grief for an owl is likened to a ruined hut, or a person who retreats to grief is like an owl who lives in a place of desolation. This is why the image of the owl is so common in classical literature.

Along with the Turkic word "owl" ("Boyqush" in Turkic), Navoi also used synonymous versions of assimilation, such as Chugz, Bum, Kuf (synonymic version of "owl" in Turkic).

(Original example: Ободлар анинг зулмидин вайрона, кабутар токчалари бойкушва ошёна. Махбубул кулуб. Free translation of the extract: The flourished got ruined by their oppression, pigeon nests turned into the owl's kitchen. "Mahbubul Qulub"). All 
three of these words are Persian words meaning "owl":

Чувз бўлмиш ганжи васлинг шавқ̧идин кўнглум қуши,

\section{Захми кўп куัнглум уйи ул}

чуззнинг вайронидур.

That is, the bird of my heart has turned into an owl because of the desire to see you, and the house of my heart, full of sorrows, is the ruin of the owl, says the poet. Through this exaggerated image, a picture of the lover's anguished heart is created.

Typically, the owl's inhabitng space in the ruins comes in handy in providing a variety of figurative depictions of the creators 'heroes. For example, in "Farhod and Shirin", Shirin writes in a letter to Farhod that Farhod went out into the desert and became friends with wild animals and birds:

Хумойи ишратинг маъдум экинму,

Бошингzа соя солвон бум экинмув?

In the epic, the state of love is more vividly revealed by the contrast between the words "humo" and " boom" ( symbolic birds from Turkic classical literature). Humo represents the image of happiness, the image of the state, and the owl represents the image of sorrow. Giving the expression of the state of mind in real images ensured the vitality of the image.

Navoi used the synonyms "chugz" and "kuf" (which can be translated as owl) in the work "Lisonut tayr". In the chapter where one of the thirty birds that set out in search of Simurgh apologized to the leader Hudhud for fear of Kuf's arrogance (Simurgh, Hudhud, Kuf are bird heroes in Navoi's book Lisonut tayr) Alisher Navoi used the image of an owl to refer to people who spent their lives in vain in search of wealth, it is expressed that the hearts of such people are doomed to darkness, that such souls are in ruins, that there is no light (humanity) in them.

Pleonasm occurs when words that are synonymous or semantically close are overused as a lexical unit. Synonyms, which are the primary sources of emotional-expressive lexicon, are one of the main factors in determining the richness of the existing language, the level of development. Synonyms are used pleonastically according to two poetic requirements:

a) Lexemes with a unifying sema differ from each other by levels of expression, one of which is specific to poetic speech. For example, the Persian word for friend, "oshno, hamdam" in the Uzbek language, which means "friend"; The same can be said of Arabic synonyms such as "rafiq, muhib, harif, habib, mahbub, anis". The word comrade, which belongs to the noun family, has been used since ancient Turkic times, "... there is no doubt that it was formed by adding the suffix -q to the base of the original verb, but there is no evidence in sources to prove the existence of a middle verb meaning" be equal " [2]. This is also mentioned in E.V. Sevortyan's dictionary [3].

From the Persian synonyms of the word comrade, the word friend (do'st) (دوست)has the etymological meaning of "compassionate friend, companion, accompany, " [4], the word "acquaintance" ("oshnnạ) (آشنا) (5) )means "acquaintance", "comrade" [5], accompany hamdam (hamdam ) هدم) is also the word for "companion, companion; comrade, friend "[6]. Also, from the Arabic synonyms of the word comrade, the word rafiq (rafiyq) means "companion; partner, comrade, friend; means "beloved" [7] the word muhib (محب) means "lover, friend" [8], the word harif (حريف) means "comrade, partner" [9], the word habib (حبيب) (habiyb) means "beloved, friend" [10], mahbub (Mahbub) the word "beloved; mistress; friend "[11], the word anise (انيس) (anys)“" ulfat; friend, close, comrade; means "neighbor" [12]

When Navoi refers to the lyrical protagonist ('yor'), he refers to lexemes, often from Arabic and Persian, rather than the traditional expressions available in the Turkic language, and avoids two repetitions. Firstly, it gets rid of the simple repetition, and secondly, it achieves the bulging of the poetic image, the background coloring. For example, in the poetic text the versions muhib, mahbub, habib are more expressive, and therefore Navoi uses these words 
in more poetic works. The poet can be considered to have achieved the above-mentioned goal by using pleonastic consecutive use of the Arabic synonyms muhib, mahbub, habib in the sense of "beloved" in the ghazal poem "O habib".

Хақ ўзин қ̧илди мухчиб сен ойни махсубб, эй хุабиб,

Ул мухчибқ̧а сен киби махчууб эрур хўб, эй хุабиб. (Navodir un-nihoya).

b) lexemes with a unifying sema differ in their emotional-expressiveness, from which they are selected for poetic speech. For example, the word "visible" differs from the lexemes clear, appeared, revealed, obvious, apparent, which are synonymous in the meaning of "visible, revealing", by its emotional coloring. Here the word "open" "ochiq" Turkic lexeme is formed by adding the affix -iq (-yq) to the all-Turkic words ach (ach) meaning to open [13] where the lexemes ayan (عاين) ('ayn) and zahir (ظاهر) (zahir) are Arabic, while the words appeared (payda) (يُهان) and oshkar (ậshkarar) (آنشكار)are Persian. Note the following byte from the Badoe' ul-bidoya divan:

Менга не манзилу маъво аён, не хонумон пайдо,

Не жонимдин агар зохуи, не кўнглумдин нишон пайдо.

The Turkic, Persian, and Arabic synonyms in this byte are used pleonastically to express the exact same concept, and the synonyms are sequentially emotional, figurative, and expressive. When synonyms are pleonastic in a byte or verse, often one of them is elevated to the level of poetism, where it is more accurate to say the same about synonyms of the word "zahir" (external, clear, apparent).Accordingly, the synonym of the word zahir cannot be replaced by alternatives such as explicit, external, these lexemes cannot fully express the meaning of the word zahir and do not meet the weight requirement (specific requirement of the classical oriental poetry). "Synonyms allow to avoid repetitions in speech, to make speech smooth ..." [14], the side-by-side use of words forming a synonymous series in a poetic text can be seen as a manifestation of lexical redundancy.

\section{Results and Discussions}

It can be observed that Navoi used words in a parallel style from three languges such as puppet = "qo'g'irchoq" (the same word in the modern Uzbek language) to mean "children's toy made to look like a humanbeing or something" in the old Turkic qovurchoq (a phonetic variant of the lexeme "qo'g'irchoq") and while in Arabic lu'bat and in Persian-Tajik bozicha. Navoi used the pleonastic use of Turkic and Arabic synonyms in the following places, revealing expressiveness that prevented repetition:

Ема бозики, луъбатбоз эрур гардун фарсангва,

Бу луъбатларки, эл кўнглин олур анинг қовурчоzи. (Favoid ul-kibar).

Navoi creates a new poetic image by using an Arabic alternative instead of a Turkic lexeme. While Navoi introduces Persian and Arabic alternatives of Turkic lexemes into the text according to the poetic demand, in many places he uses assimilations in his own words, as a result of which these words will not be incomprehensible to the reader.

Poetic speech requires a clear, figurative expression of artistic intention. In this case, the position of any word increases, manifesting itself as a means of speech. Accordingly, in many cases the possibility of substituting a word for a poetic text with its synonym is eliminated.

The reason is that the poetic text is inextricably linked with its formal aspect. In particular, the "aruz vazn" which is a poetic weight requirement in the application requires the very characteristics mentioned above. Navoi used Turkic words such as "chul and yozi" to mean desert, Arabic "sahro, bodiya", Persian "dasht, biyobon, yobon" to mean "a steppe with very little vegetation, a constant dry and hot climate, and no water." It is desirable to indicate the place of use of these lexemes in the epic "Khamsa" in the following table which are from three mentioned languages : 


\begin{tabular}{|l|l|l|l|l|l|l|l|}
\hline "Khamsa" & Cho'l & Yozi & Sahro & Bodiya & Dasht & Biyobon & Yobon \\
\hline $\begin{array}{l}\text { "Hayratul- } \\
\text { abror" }\end{array}$ & & + & & & & & \\
\hline $\begin{array}{l}\text { "Farhod and } \\
\text { Shirin" }\end{array}$ & + & & + & & + & + & \\
\hline $\begin{array}{l}\text { "Layli and } \\
\text { Majnun" }\end{array}$ & & + & + & + & + & + & \\
\hline $\begin{array}{l}\text { "Sa'bai sayyor" } \\
\text { "Saddi } \\
\text { Iskandariy" }\end{array}$ & & & + & & + & + & + \\
\hline
\end{tabular}

In lexical redundancy, "the presence of identical or synonymous means of expression, ie, linguistic units without semantic repetition" [15], occurs for the purpose of defining the content, and in some cases increases the artistic content as a stylistic figure [16]. The possibility of synonyms in all forms of speech is wide, because the words in the synonymous series differ from each other in the expression of positive or negative attitudes, stylistic peculiarities, the degree of spiritual coloring. It is advisable to use synonyms in place to avoid simplicity, clarity, or intellectual ambiguity of expression. A number of studies have been conducted in this regard. Synonyms are used sequentially in poetic expression to ensure imagery, emotionality, clarity, charm, emphasis:

The adjectives of color in the modern Uzbek literary language can be divided into two groups according to their structural structure and semantic features: 1. Primitive adjectives of color; 2. Artificial qualities that express color. The issues of the emergence and development of colorexpressing qualities in language are also related to the general development and its stages. The adjectives of color in the modern Uzbek literary language can be divided into two groups according to their structural structure and semantic features: 1. Primitive adjectives of color; 2. Artificial qualities that express color. The issues of the emergence and development of colorexpressing qualities in language are also related to the general development and its stages.

It is also known that the word "qizil" red is one of the most ancient and basic words of the
Uzbek lexicon [18]. In Yusuf Khas Hajib's Qutadg'u Bilig, the meaning of "face, righteousness" is expressed in the most lexemes of the work. (QB, 469).

B.Bafoev: "The fact that the main morpheme of the word red "qizil" appears in two phonetic versions as Qiz-qir shows that this main morpheme is also artificial. Because with red, there is also a red color, which indicates the sense of the same color, and its main morpheme is the "qir" stem element.

Ancient Turkic written sources found in Kyrgyzstan and Mongolia used the word" kyryg" to denote red. "[19] The scientist also hypothesizes that the morphological structure of qiz // qir morphemes should be qi $+z$ and qi $+r$. Based on this idea, the words "qirgu and qizgu" have historically been two variants of the same word. Мумтоз адабиётда, хусусан, Алишер Навоий асарларида рамзий маънода ёр таъриф ва тавсифида қзизл варианти қўлланган ўринлар кўп учрайди, масалан, “То қизил тўн ичра булди жилвагар мохим менинг” ёки “Эй Навоий, қатл учун гар худ қизил туин кийди ёр" каби. In classical literature, especially in the works of Alisher Navoi, there are many places where "qizil" to mean the red version is used in the symbolic definition and description of "yor", for example,

"То қизил тугн ичра бўлди жилвагар мохчим менинг” оr "Эй Навоий, қ̧атл учун гар худ қизил тугн кийди ёр".

Also, in the works of the poet, borrowed words from Persian-Tajik languages such as 
"gulᄀgun, maygun, lolagun, gulfom, gulnor, gulnorgun, argavongun, shingarf "lexemes represented the "red" semantics. In particular, the expansion of semantic coverage in the Persian word flower lexemes, combinations and suffixes is reflected in the fact that the "red" sema has a significant place in the normative or redundant levels.

For example, in the semantics of such forms as "gulgun, gulguna, gulgaz, gulnor, gulnorgun, gulnoriy, gulfom, gulrang, otashin gul, guli savriy", the meaning of "red" has a denotative meaning or derivative meaning.

The combination of fiery flowers used in the poet's works means "fiery flower, red flower like coals", for example, in the verse "Suppose a spot of fire is like a flower on the hijra", refer to the color of fire made.

Even in the repetitive structure of the flower lexeme, there is a semantic expansion, which means "crimson" in the context.

In the verse "Does your face bloom?", The lover's address is addressed to the lover: "Did your red tears make your face red?" created harmony.

Also, in the works of the poet, Turkish or masculine words (La'ling oyo ne ajab rangdur) belonging to the category of nouns, such as tulip, agate, ruby, dawn, blood, la'l, mean "red". It is known that in Arabic the adjectives denoting all colors are made up of verbs [20],

In the works of Alisher Navoi, the Arabic words o (a) 1, humro (hamro), ahmar adjectives are used. Although the word ruby means "redness" in classical literature, the ruby gemstone is red, yellow, blue and white, and red was popular, which is probably why Alisher Navoi often used the addition of ruby ahmar (red ruby). For example, "The stone of your roads is the ruby red." In eliminating repetition, the poet often uses two lexemes belonging to the category of noun and adjective, meaning "red" in one verse. For example, “Қон ёшим аксиму ол этмиш фалак миръотини" mean the redness of the sky reflects my bloody tears is the artistic exaggeration used in authors work.
In some of the poet's ghazals, lexemes meaning "red" are given in each verse of the ghazal in order to increase the poetic value and to give a full description of the companion. For this purpose, we turned to Alisher Navoi's ghazal, which begins The lexeme of "lolagun" was first used in the text of the ghazal:

Лолагун тугн ичра, ё раб, ул вазоли Чин эрур

$\ddot{E}$ куззумнунг мардуми қон ёш ила рангин эрур.

According to the lover, when he wears a half-red cloak, it resembles a Chinese owl, and in the next verse, or because of the bloody tears shed from my eye, it seems to me that the cloak looks so bright (red). Here it refers to the color red by the word blood belonging to the noun family.

Билмон, оёким, шафақ ичра эрур заррин вазол,

Лолагун тунн ичра ёхуд ул
вазоли Чин эрур.

The lover exaggerates that the wound in the red cloak is perhaps the sun itself in the redness (dawn) that appears in the sky at sunset, and repeats the idea of the first verse of the matla (the first two lines of ghazals). In this case, the Arabic lexeme dawn means "red".

Original example:

Айламиш гулдаста банди сунъ тўну жисмини,

Санъатиким, арвувон барги аро насрин эрур.

In the eyes of the lover, the poet chains the body like flowers in a bouquet, the poet creates an original poetic image, that is, the leaves of the prose flower (known prose flower is white, in our opinion, the poet refers to the body color of the mistress) are depicted in purple. The lexeme Arguvan was originally used to mean "red flower tree" [21], meaning "red" in classical literature.

Original example:

Қадмудур бу ё эрур шингарф ила ёзгон алиф,

Белму ё тореки, лаъл ичра анга таскин эрур. 
The lover, who was amazed at the height of the scarf wearing a red cloak, said that it was kadmikan or the letter alif written in red (shingarf). In the description of mistress's waist, he exaggerates whether it is a waist or single string of hair (narrow), immobile in a red ton (la'l). Here, the red ton is indicated by the dumb lexeme, which means "red gemstone".

Original example:

...Бир қ̧адах гулгун май, эй соқ̧ий, тулла тутким, куингул

Ул бути гулгун қุабо бедодидин вамгин эрур.

Usually, in classical literature, Allah is referred to as a "soqiy" who serves drinks, and drink is the symbol of love, and red wine is also symbolic, i.e., the path of love is painful, heavy; the lover is saddened by the oppression of the red dress he cares for. At this point, the Persian word "gulgun" means "red".

Original example:

Эй Навоий, қุатл учун гар худ қиизил тугн кийди ёр,

Басдур ул тугн ранги, не мухтожи қатлу кин эрур.

According to the poet, the friend was aiming to kill the lover, who was wearing a red cloak, and the lover now fully understood that the color of the cloak was a sign that he was ready to kill the lover as an enemy. In this byte, the semantics "red" are explicitly expressed by the red lexeme, while in the tone color combination they are implicitly expressed.

Original example:

Дема тову лола дахр ичра - ажал қооллони бил,

Ким кийиклар қ̧онидин бошдин аёz рангин эрур

In the praise of the ghazal, the words tulips and blood are used to refer to the word "red" in the category of noun. The poet proves his point beautifully, that is, the tulips in the mountains should be known as the leopard of death in the world, in fact, he concludes his idea with the artistic content that they are adorned from head to toe with the color of deer blood.
In Alisher Navoi's works, the Turkic, Persian, Arabic lexemes meaning "red", izophas, artificialities created by the poet, along with the need for rhyme and poetic weight, served to eliminate repetition, to ensure the artistry of the poetic image enriched our language, as well as proved the richness and variety of its lexicon, its full awareness not only of the lexeme but also of its semantic scope, showing a serious attention to word and meaning.

\section{Conclusion}

Alisher Navoi's ability to use each lexeme and its synonymous versions, as well as his great attention to the word, the semantic aspects of the word, is evident in the use of synonyms.

Often the Arabic lexemes in the synonymous series are aimed at revealing the poet's intention in their own and figurative senses. This was manifested as a subtle aspect of the great poet's skill. Often the Arabic lexemes in the synonymous series are aimed at revealing the poet's intention in their own and figurative senses. This was manifested as a subtle aspect of the great poet's skill. Navoi sought to show the richness of the lexical reserve of the Turkic language through the pleonastic use of Persian and Arabic synonyms of the Turkic lexeme, as well as enriched the lexical reserve of the Turkic language.

\section{References}

[1] Egamova Sh. Research of ancient Turkic lexicon in the language of Alisher Navoi's works (in structural-grammatical, functional-semantic aspects): Candidate of Philological Sciences diss. -Tashkent, 2007. -B.9.

[2] Rahmatullaev Sh. Etymological dictionary of the Uzbek language (Turkish words). Tashkent: Universitet, 2000. -B.489.

[3] Sevortyan E.V. Etimologicheskiy slovar tyurkskix yazykov (obshchetyurkskie i mezhtyurkskie osnovy na glasnye). Moscow: Nauka, 1974. -S.476-477. 
[4] Annotated dictionary of the Uzbek language. 5 volumes. Volume 1 Tashkent: UzME, 2006. -P.677.

[5] Rahmatullaev Sh. Etymological dictionary of the Uzbek language (Persian, Tajik units and their derivatives). -Tashkent: Universitet, 2009. -B.176.

[6] Shamsiev P., Ibrohimov S. Dictionary of Navoi works. -T., 1972. -B.763.

[7] Annotated dictionary of the Uzbek language. 5 volumes. Volume 3 Tashkent: UzME, 2007. -P.357.

[8] Shamsiev P., Ibrohimov S. Dictionary of Navoi works. -Tashkent, 1972. -P.440.

[9] A short dictionary for the works of Navoi. -Tashkent: Fan, 1993. -P.367.

[10] Shamsiev P., Ibrohimov S. Dictionary of Navoi works. -Tashkent, 1972. -P.757.

[11] Annotated dictionary of the language of Alisher Navoi's works. Volume IV. I skin. -Tashkent: Fan, 1983. -P.286.

[12] Shamsiev P., Ibrohimov S. Dictionary of Navoi works. -Tashkent, 1972. -P.52.

[13] Sevortyan E.V. Etimologicheskiy slovar tyurkskix yazykov (obshchetyurkskie i mezhtyurkskie osnovy na glasnye). Moscow: Nauka, 1974. -S.209-210.

[14] Lexicology of the Uzbek language. Tashkent: Fan, 1981. -B. 244.

[15] Mahkamov N. Literary norm and pleonasm. -Tashkent: Fan, 1988. -B.17.

[16] http: // yandex.ru. Kviatkovskii A.P.Pleonazm // Kviatkovskii A.P. Poetic dictionaries '. - M .: Sov. Entsikl., 1966. S.215.

[17] Sodikova M. Colorful words in the Uzbek language: candidate of philological sciences diss. -Tashkent, 1963. -P.48-51.

[18] Pardaev Z. Study of color-expressing qualities // Language and literature education. - Tashkent, 2003. - № 3. -B.16.

[19] Bafoev B. History of ancient words. Tashkent, 1991. -B.142.

[20] Tojiboeva M. Lexical-semantic interpretation of Arabic words in Alisher Navoi's "First Devon": Philol. fan. candidate diss. avtoref. -Tashkent, 2011. P.13.

[21] Hasanov B. A concise dictionary of Navoi's works. -Tashkent, 1993. -P.28.

[22] Annotated dictionary of the language of Alisher Navoi's works. 4 volumes. Volume 1 / Edited by E. Fozilov / - Tashkent, 1983. - P.414.

[23] Muhamadjonovna, S. D. (2020). A Set Of Methodological Tools For The Formation Of Sociolinguistic Competence Of Future English Teachers. The American Journal of Social Science and Education Innovations, 2(12), 298-302.

[24] Sarimsakova, D. (2017). Station Rotation. English Teaching

Professional, 109. 